\title{
Occurrence of the Stringent Response in Streptomyces sp. and its Significance for the Initiation of Morphological and Physiological Differentiation
}

\author{
By KOZO OCH I \\ Exploratory Research Laboratories, Fujisawa Pharmaceutical Co. Ltd, 5-2-3 Tokodai, \\ Toyosato-cho, Ibaragi-ken 300-26, Japan
}

(Received 20 March 1986; revised 22 April 1986)

\begin{abstract}
Streptomyces sp. MA406-A-1 produced formycin (a nucleoside antibiotic) in parallel with cell growth in a synthetic medium. When the synthetic medium was supplemented with $1 \%(\mathrm{w} / \mathrm{v})$ Casamino acids, however, formycin was produced only after the end of exponential growth. The intracellular ppGpp pool increased gradually towards the end of exponential growth and was maximal at the beginning of formycin production. After shift down from Casamino acids medium to synthetic medium, the ppGpp pool increased immediately, while the GTP pool decreased; under such conditions, the ability to produce formycin increased eightfold. Relaxed (rel) mutants, the first isolated for a Streptomyces species, were found at high incidence $(10 \%)$ among spontaneous thiopeptin-resistant isolates and had severely reduced abilities to accumulate ppGpp. These rel mutants also failed to produce formycin under the usual culture conditions and exhibited numerous pleiotropic effects such as an inability to produce melanin and an extended delay of aerial mycelium formation. Thus Streptomyces sp. exhibited a typical stringent response, and the response initiated (or was needed for) the induction of secondary metabolism. The response may have also participated in the initiation of aerial mycelium formation by decreasing the intracellular GTP pool.
\end{abstract}

\section{INTRODUCTION}

Streptomyces is a genus of the order Actinomycetales. A distinguishing characteristic of species of this genus is their ability to form aerial mycelium from substrate mycelium when cells encounter adverse environmental conditions such as nutrient limitation. The aerial mycelium subsequently can form spores (conidiospores), perhaps one of the most evolved differentiation processes in prokaryotic micro-organisms. Consequently, the formation of aerial mycelium and conidiospores by Streptomyces has been studied as a model for differentiation (Kalakoutskii \& Agre, 1976; Ensign, 1978; Chater \& Merrick, 1979; Chater, 1984).

Members of the genus Streptomyces also produce numerous antibiotics, which has been regarded as an example of 'secondary metabolism' as the cells do not need to produce antibiotics to grow normally. Although Streptomyces species produce antibiotics at about the same time that the mycelium undergoes differentiation, no causal links have been established between differentiation and formation of these secondary metabolites (Chater, 1984). Thus, Streptomyces are excellent organisms in which to study both differentiation and secondary metabolism.

In Bacillus subtilis and Escherichia coli, amino acid limitation produces the 'stringent response' whereby the rate of RNA synthesis and of numerous other cellular reactions, including GTP synthesis, is severely reduced. This effect is accompanied by an increase in the intracellular concentrations of ppGpp and pppGpp, compounds believed to be responsible for the stringent response (Cashel, 1975; Gallant, 1979). The stringent response can be avoided by the introduction of genes having the relaxed genotype. The best known is relA (Fiil \& Friesen, 1968; 
Swanton \& Edlin, 1972), a mutation in the gene that codes for the factor needed for the synthesis of ppGpp and pppGpp (Block \& Haseltine, 1973; Smith et al., 1978). Another mutant gene is relC (Friesen et al., 1974; Smith et al., 1978), which codes for ribosomal protein L11 (Parker et al., 1976; Smith et al., 1980). During amino acid starvation in $E$. coli or B. subtilis, mutants carrying the relaxed genotype ( $\mathrm{relA}$ and $\mathrm{relC}$ ) accumulate neither ppGpp nor pppGpp (Cashel, 1975; Gallant, 1979). However, mutants of $E$. coli (but not of $B$. subtilis) bearing either the relA or the relC gene can still accumulate ppGpp during a shift down of energy source, e.g. glucose deprivation (Lazzarini et al., 1971; Friesen et al., 1974). The occurrence of the stringent response in Streptomyces sp. has been described by Riesenberg et al. (1984).

The importance of the stringent response for differentiation has been demonstrated in $B$. subtilis (Freese, 1981; Freese \& Heinze, 1984) and Myxococcus xanthus (Kaiser, 1984). In $B$. subtilis the decrease of intracellular GTP, caused by the stringent response (or more directly by the inhibitors of GMP synthesis), results in an initiation of sporulation (Lopez et al., 1981; Ochi et al., 1981, 1982). Aerial mycelium formation of Streptomyces has also been shown to be initiated by the addition of decoyinine (a specific inhibitor of GMP synthesis), which caused a decrease in the pool of GTP (Ochi, 1986). The results with B. subtilis showed that the stringent response initiates both sporulation and antibiotic production, but by different mechanisms (Ochi \& Ohsawa, 1984; Ochi, 1985).

By isolating relaxed mutants of Streptomyces sp. MA406-A-1, I show in this paper that the stringent response (ppGpp) is needed to initiate formycin production in this organism.

\section{METHODS}

Source of drugs. ppGpp and pppGpp were purchased from Sanraku Co., Fujisawa, Kanagawa, Japan, DL-serine hydroxamate and $\mathrm{D}(-)$ threo-chloramphenicol from Sigma and Casamino acids (vitamin-free) from Difco. $\left[2-{ }^{14} \mathrm{C}\right]$ Uracil and $[2-14 \mathrm{C}]$ thymidine were from New England Nuclear. Formycin was a gift from Dr T. Shomura, Meiji Seika Co., Yokohama, Japan. Thiopeptin (an analogue of thiostrepton) was a commercial product of our company. All medium components were from commercial sources.

Strains and preparation of mutants. Streptomyces sp. MA406-A-1, a wild-type, prototrophic (formycin-producing) strain was provided by the Institute of Microbial Chemistry, Tokyo, Japan. The spontaneous thiopeptin-resistant mutants were obtained as resistant colonies, which developed $22 \mathrm{~d}$ after spreading spores on soluble starch/yeast extract/polypeptone agar (see below) containing $3 \mu \mathrm{g}$ thiopeptin $\mathrm{ml}^{-1}$. [Growth of the parental strain was almost completely suppressed with $1 \mu \mathrm{g}$ thiopeptin $\mathrm{ml}^{-1}$.] The resistant clones were purified by single colony isolation before subsequent study.

Growth conditions. Synthetic medium contained (per litre): glucose, $10 \mathrm{~g}$; ammonium sulphate, $2 \mathrm{~g} ; \mathrm{lysine} . \mathrm{HCl}$, $2 \mathrm{~g}$; glutamine, $2 \mathrm{~g} ; \mathrm{NaCl}, 5 \mathrm{~g} ; \mathrm{KCl}, 0.5 \mathrm{~g} ; \mathrm{MgSO}_{4} .7 \mathrm{H}_{2} \mathrm{O}, 0.5 \mathrm{~g} ; \mathrm{ZnSO}_{4} .7 \mathrm{H}_{2} \mathrm{O}, 10 \mathrm{mg} ; 1 \mathrm{M}$-sodium phosphate buffer (pH 7), $100 \mathrm{ml}$. [Lysine and glutamine were included because they are precursors of formycin biosynthesis and increase formycin production (Ochi et al., 1979).] The medium was sterilized by autoclaving at $120^{\circ} \mathrm{C}$ for $20 \mathrm{~min}$; glucose solutions were autoclaved separately. Maltose/polypeptone/yeast extract medium contained (per litre): maltose, $30 \mathrm{~g}$; polypeptone, $30 \mathrm{~g}$; yeast extract, $10 \mathrm{~g} ; \mathrm{NaCl}, 5 \mathrm{~g} ; \mathrm{KCl}, 0.5 \mathrm{~g} ; \mathrm{MgSO}_{4} .7 \mathrm{H}_{2} \mathrm{O}, 0.5 \mathrm{~g}$; $\mathrm{ZnSO}_{4} .7 \mathrm{H}_{2} \mathrm{O}, 10 \mathrm{mg} ; 1 \mathrm{M}$-sodium phosphate buffer $(\mathrm{pH} 7), 7 \mathrm{ml}$. Sporulation medium contained (per litre): soluble starch, $20 \mathrm{~g}$; yeast extract, $4 \mathrm{~g}$; agar, $20 \mathrm{~g}$. Soluble starch/yeast extract/polypeptone agar (as agar medium for formycin production) contained $0.5 \%(\mathrm{w} / \mathrm{v})$ polypeptone in addition to sporulation medium. All the media were adjusted to $\mathrm{pH} 7$ with $\mathrm{NaOH}$ before autoclaving. Plates (diameter $8.5 \mathrm{~cm}$ ) consisted of $25 \mathrm{ml}$ medium solidified with $2 \%(w / v)$ agar.

A spore suspension for inoculation was prepared by scraping the spores from a slant of sporulation medium with an inoculating loop and transferring them to a sterile test tube containing approximately 100 glass beads ( $3 \mathrm{~mm}$ diameter) and $4 \mathrm{ml}$ saline $(0.9 \% \mathrm{NaCl})$. After continuous blending on a vortex mixer for $5 \mathrm{~min}$, the spore suspension ( $3 \mathrm{ml}$ ) was inoculated into maltose/polypeptone/yeast extract medium ( $50 \mathrm{ml}$ in a $250 \mathrm{ml}$ flask). After culture for $2 \mathrm{~d}$ (for parent) or 3-4d (for mutants) at $25^{\circ} \mathrm{C}$, cells were harvested by centrifugation $(8000 \mathrm{~g}, 10 \mathrm{~min})$, washed twice with $100 \mathrm{ml}$ saline, and resuspended in the original volume of saline. Washed cells $(2 \mathrm{ml})$ were inoculated into $50 \mathrm{ml}$ synthetic medium, or synthetic medium supplemented with $1 \%(\mathrm{w} / \mathrm{v})$ vitamin-free Casamino acids (in a $250 \mathrm{ml}$ flask), and cultured at $30^{\circ} \mathrm{C}$ on a rotary shaker $(230$ r.p.m.). To determine formycin production in nutrient medium, cultured broth $(1 \mathrm{ml})$ was directly inoculated into fresh maltose/polypeptone/yeast extract medium $\left(50 \mathrm{ml}\right.$ in a $250 \mathrm{ml}$ flask), and cultured at $25^{\circ} \mathrm{C}$. [Formycin production with maltose/polypeptone/ yeast extract medium decreased markedly if the culture was grown at $30^{\circ} \mathrm{C}$ instead of $25^{\circ} \mathrm{C}$.]

Curing of formycin production. Streptomyces sp. MA406-A-1 was grown in maltose/polypeptone/yeast extract medium at $25^{\circ} \mathrm{C}$ for $2 \mathrm{~d}$. Portions $(0.5 \mathrm{ml})$ were inoculated into $50 \mathrm{ml}$ of the same medium but containing $5 \overline{\mu g}$ 
acriflavin $\mathrm{ml}^{-1}$, and cultured at $25^{\circ} \mathrm{C}$ for $1 \mathrm{~d}$. This procedure was repeated to increase curing efficiency. The cultured broth was homogenized with glass beads as described above and plated onto soluble starch/yeast extract/polypeptone agar after suitable dilution. Colonies that developed after $5 \mathrm{~d}$ incubation at $30^{\circ} \mathrm{C}$ were examined for formycin production (see below) in maltose/polypeptone/yeast extract medium or on soluble starch/yeast extract/polypeptone agar.

Assay of nucleotide pools. Cells growing in $200 \mathrm{ml}$ synthetic medium supplemented with $1 \%$ Casamino acids were collected on a filter paper (diameter $9 \mathrm{~cm}$, no. 2, Toyo Roshi Co.) and washed with $50 \mathrm{ml}$ synthetic medium, and the filters plus cells were quickly transferred to $200 \mathrm{ml}$ synthetic medium. After incubation at $30^{\circ} \mathrm{C}$ for the indicated time, the cells from $100 \mathrm{ml}$ culture were rapidly collected as just described (without washing), and the filter was then immediately laid upside down onto $10 \mathrm{ml} 1 \mathrm{M}$-formic acid in a Petri dish; the entire collection procedure was done within $15 \mathrm{~s}$. A separate $100 \mathrm{ml}$ sample was used to determine the dry cell mass. After $1 \mathrm{~h}$ incubation at $4{ }^{\circ} \mathrm{C}$, the filter paper was removed by centrifugation $(5000 \mathrm{~g}, 10 \mathrm{~min})$. The supernatant fraction was filtered through a syringe $(10 \mathrm{ml})$ fitted with a Millipore HAWP filter $(0.45 \mu \mathrm{m}$ pore size) to remove all remaining debris and then vacuum-evaporated to dryness for $10 \mathrm{~h}$. The residue was dissolved in $300 \mu \mathrm{l}$ deionized water. For the assay of nucleotides by HPLC, $50-100 \mu \mathrm{l}$ of the dissolved residue was applied to a column of Particil PXS 10/25 SAX (Whatman), which had previously been washed with $0.05 \mathrm{M}-\mathrm{H}_{2} \mathrm{SO}_{4}$ followed for $10 \mathrm{~min}$ with a high ionic strength buffer (see below) and then for $15 \mathrm{~min}$ with a low ionic strength buffer (see below). The nucleotides were eluted as described by Ochi et al. (1981) at a flow rate of $1.5 \mathrm{ml} \mathrm{min} \mathrm{m}^{-1}$, using a gradient of ionic strength made up by mixing a low ionic strength buffer $\left(7 \mathrm{mM}-\mathrm{KH}_{2} \mathrm{PO}_{4}\right.$, adjusted to $\mathrm{pH} 4$ by $\left.\mathrm{H}_{3} \mathrm{PO}_{4}\right)$ and a high ionic strength buffer $\left(0.5 \mathrm{M}-\mathrm{KH}_{2} \mathrm{PO}_{4}+0.5 \mathrm{M}-\mathrm{Na}_{2} \mathrm{SO}_{4}\right.$, adjusted to $\mathrm{pH} 5.4$ by $\left.\mathrm{KOH}\right)$. The amount of each nucleotide was determined by comparison with the peak areas of materials eluted from HPLC columns and that of known amount of authentic nucleotides. The peak areas in absorbance profiles were automatially integrated by a computer (Hitachi 655-61, processor A). To normalize the amounts of nucleotides in different cultures, they were expressed relative to the cell dry weight measured at the time of harvesting, i.e. pmol (mg dry wt) ${ }^{-1}$.

Determination of cell dry weight. Cells from $100 \mathrm{ml}$ culture were collected on filter paper (diameter $4 \mathrm{~cm}$, no. 2 , Toyo Roshi Co.) and washed with $200 \mathrm{ml}$ deionized water. The filters with cells were then dried in an oven at $60^{\circ} \mathrm{C}$ for $\mathbf{4 h}$ and weighed after cooling in a desiccator.

Assay for formycin. Formycin was determined by a disc-plate method with Xanthomonas oryzae IFO 3312 as a test organism as described by Ochi (1986).

Determination of RNA or DNA synthesis. The cells, grown to mid-exponential phase, were harvested and resuspended to $\mathrm{OD}_{600}=2$ in the specified medium containing $50 \mu \mathrm{M}-\left[2-{ }^{14} \mathrm{C}\right] \mathrm{uracil}\left[0.05 \mu \mathrm{Ci} \mathrm{m} l^{-1}\left(1.85 \mathrm{kBq} \mathrm{ml}^{-1}\right)\right.$, for RNA synthesis] or $20 \mu \mathrm{M}-\left[2-{ }^{-14} \mathrm{C}\right]$ thymidine $\left[0.03 \mu \mathrm{Ci} \mathrm{ml}^{-1}\left(1.11 \mathrm{kBq} \mathrm{m}{ }^{-1}\right)\right.$, for DNA synthesis], and incubated at $30^{\circ} \mathrm{C}$ with shaking. Samples $(1 \mathrm{ml} \mathrm{each})$ were removed at the indicated times and immediately added to $1 \mathrm{ml}$ ice-cold $10 \%(\mathrm{w} / \mathrm{v})$ TCA. After standing for $1-2 \mathrm{~h}$ at $0{ }^{\circ} \mathrm{C}$, the suspensions were collected on membrane filters (Millipore HAWP, $0.45 \mu \mathrm{m}$ ), which were then washed with $5 \mathrm{ml}$ ice-cold $5 \%(\mathrm{w} / \mathrm{v})$ TCA. Radioactivity on the filters was estimated in a liquid scintillation counter with Aquasol (New England Nuclear) as scintillation fluid.

Reproducibility. The experiments shown in each Figure were repeated at least once to confirm reproducibility (except that in Fig. 1, which was not repeated); representative results are presented.

\section{RESULTS}

\section{Growth and formycin production}

In contrast to the growth of unicellular bacteria, the growth pattern of streptomycetes is one of hyphal elongation with branching and leads to the formation of clumps. The physiology within and outside these clumps may differ because of differences in nutrient transport. In this study clumping was largely avoided by inoculating relatively large amounts of mono-spore suspensions in making precultures (see Methods); consequently, the cell populations described below are expected to be more uniform than those in previously described studies.

When cells were inoculated into synthetic medium, they produced formycin during the exponential growth phase and ceased production when growth ended. In contrast, cells did not produce formycin during the exponential growth phase if the medium was supplemented with $1 \%(w / v)$ Casamino acids but began producing it after the end of exponential growth, showing a typical pattern of secondary metabolite synthesis.

The changes in intracellular nucleotide pool size during growth in synthetic medium supplemented with $1 \%(w / v)$ Casamino acids were measured (Fig. 1). The pool size of ppGpp during early exponential growth was very low $\left.[2-4 \text { pmol (mg dry wt })^{-1}\right]$ but it increased towards the end of exponential growth. A drastic increase was observed around $20 \mathrm{~h}$, at which time cells had just entered stationary phase, apparently due to exhaustion of nutrient(s) which would 


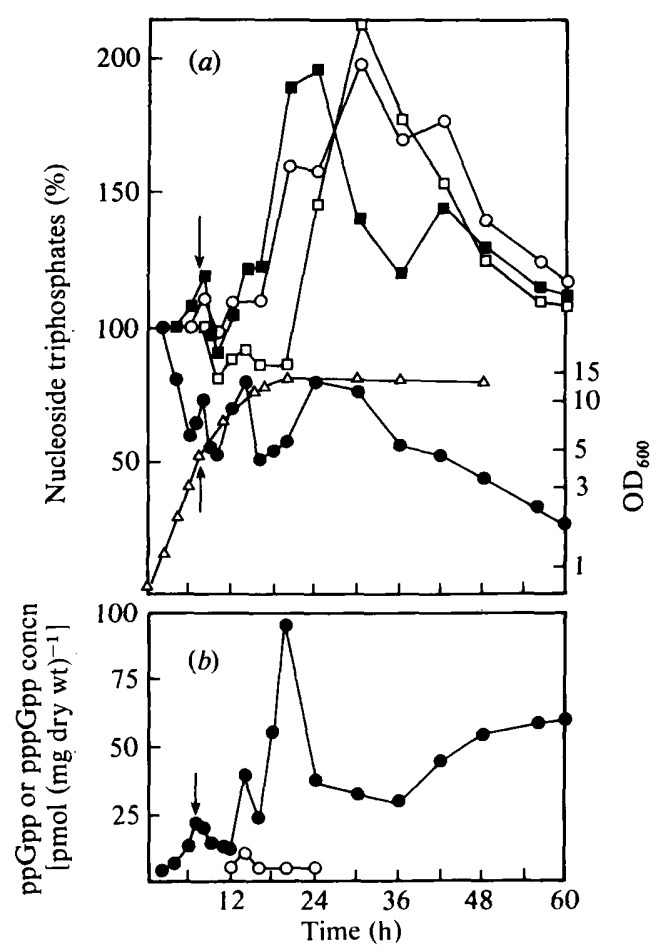

Fig. 1. Changes in the intracellular concentrations of nucleoside triphosphates, ppGpp and pppGpp during growth in synthetic medium supplemented with Casamino acids. Streptomyces sp. MA406-A-1 was grown in synthetic medium plus $1 \%(\mathrm{w} / \mathrm{v})$ Casamino acids. At each of the indicated times, samples $(20-100 \mathrm{ml})$ were withdrawn from the cultures, filtered and extracted as described in Methods. The pool size of each nucleotide at $2 \mathrm{~h}$ [pmol (mg dry wt) ${ }^{-1}$ ], designated as $100 \%$, was: GTP, 1020; CTP, 403; ATP, 2060; UTP, 734. The arrows indicate the time at which exponential growth ceased. (a) $\triangle, \mathrm{OD}_{600}$ of culture; O, GTP; O, CTP; $\square$, ATP; $\square$, UTP. (b) ○, ppGpp; O, pppGpp.

increase the fraction of uncharged tRNA. At the same time, ATP, CTP and UTP all increased markedly, possibly due to arrest of RNA synthesis. When cells were grown in synthetic medium, relatively high levels of ppGpp [15-22 pmol (mg dry $\left.\mathrm{wt}^{-1}{ }^{-1}\right]$ were detected throughout the exponential growth phase (results not shown).

A small amount of chloramphenicol $\left(0.7 \mu \mathrm{g} \mathrm{ml}^{-1}\right.$, added just after inoculation) reduced formycin production by $65 \%$ without affecting growth. Since chloramphenicol inhibits ppGpp synthesis in B. subtilis (Ochi \& Freese, 1983), these results raised the possibility that ppGpp is the physiological initiator of formycin production. To assess this possibility, I isolated relaxed (rel) mutants which might lack the ability to produce ppGpp.

\section{Isolation of rel mutants}

Relaxed (relC) mutants, lacking ribosomal protein BS-L11, have been previously recovered from $B$. subtilis cells as thiostrepton-resistant isolates (Smith et al., 1978). In the present study I used thiopeptin [an analogue of thiostrepton; see Hensens \& Albers-Schönberg $(1983 a, b)$ for its structure] to isolate drug-resistant mutants of Streptomyces sp. MA406-A-1. A number of thiopeptin-resistant colonies developed on the plates containing $3 \mu \mathrm{g}$ thiopeptin $\mathrm{ml}^{-1}$ after $22 \mathrm{~d}$ incubation with a frequency of about $2 \times 10^{-8}$.

Among these, 20 strains selected randomly were tested for the ability to produce ppGpp during nutritional shift-down. Strains growing exponentially in synthetic medium supplemented with $1 \%$ Casamino acids were harvested and resuspended in synthetic medium (without Casamino acids). After a $10 \mathrm{~min}$ incubation, cells were collected and extracted and the extracts 


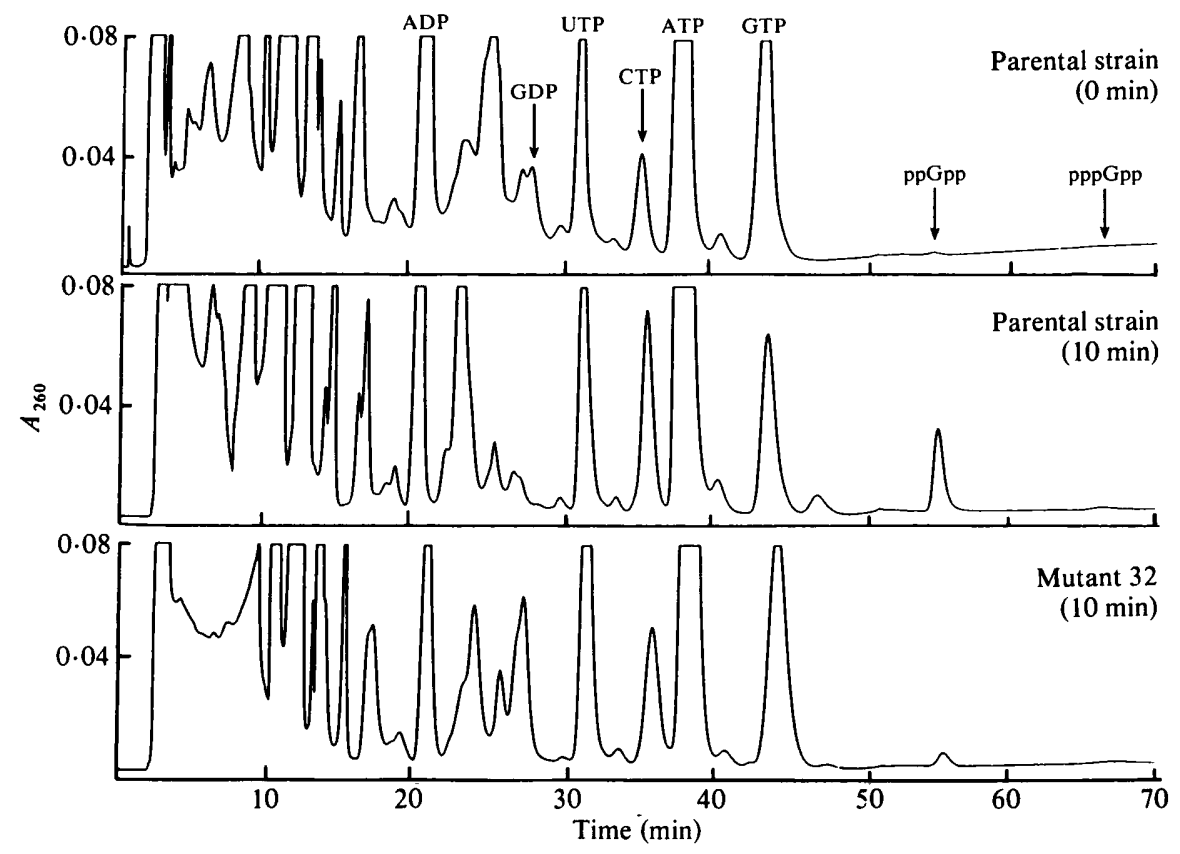

Fig. 2. Elution profile of nucleotides extracted from cells of the parental strain (MA406-A-1) or mutant 32 after deprivation of Casamino acids. The strains, grown to mid-exponential phase (for $4 \mathrm{~h}$ in parent, for $6 \mathrm{~h}$ in mutant) in synthetic medium plus $1 \%(\mathrm{w} / \mathrm{v})$ Casamino acids, were harvested and transferred to fresh synthetic medium (without Casamino acids). After $10 \mathrm{~min}$ incubation with shaking, cells were collected and extracted and the extracts analysed by HPLC. Samples applied were equivalent to 15$17 \mathrm{mg}$ cell dry wt in each profile.

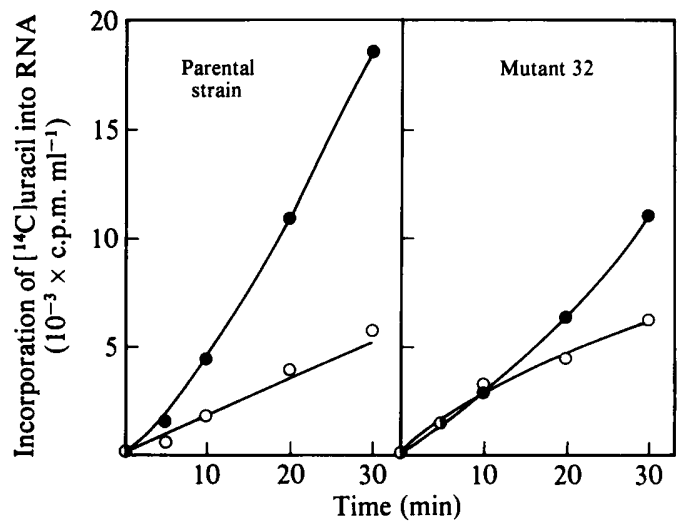

Fig. 3. Effect of deprivation of Casamino acids on RNA synthesis by cells of Streptomyces sp. MA406A-1 and mutant 32. Cells, grown with $1 \%(\mathrm{w} / \mathrm{v})$ Casamino acids as in Fig. 2, were transferred to synthetic medium containing $[2-14 \mathrm{C}]$ uracil with $(O)$ or without $(O)$ Casamino acids and incubated with shaking for $30 \mathrm{~min}$ (see Methods).

analysed by HPLC (see Methods). Two strains (32 and 123) accumulated severely reduced amounts of ppGpp, compared with the parental strain (Fig. 2). Strains 32 and 123 appear to be different mutants because their colony morphologies differ. The other 18 strains examined accumulated as much ppGpp as the parental strain (not shown). Mutant 32 was examined for its ability to synthesize RNA during amino acid starvation. As shown in Fig. 3, the RNA synthesis of the parental strain (MA406-A-1) was markedly reduced upon nutritional shift-down whereas 
mutant 32 continued RNA synthesis for at least 20 min at a rate comparable with that in the presence of Casamino acids. Mutant 123 responded to deprivation of Casamino acids in a manner similar to that of mutant 32 (data not shown). Thus, both mutants exhibited the relaxed phenotype with respect to RNA synthesis. The rel mutations were apparently leaky in both strains, as both strains still produced measurable amounts of ppGpp.

\section{Characterization of rel mutants}

The rel mutation resulted in numerous pleiotropic effects: in particular, the rel mutants produced strikingly less formycin than the parental strain in both liquid and agar-plate cultures. This deficiency was more pronounced in complex than in synthetic medium: the parental strain produced $60 \mu \mathrm{g}$ formycin $\mathrm{ml}^{-1}$ in maltose/polypeptone/yeast extract medium, while the rel mutants (32 and 123 ) produced only $1-3 \mu \mathrm{g}$ formycin $\mathrm{ml}^{-1}$. Those thiopeptin-resistant mutants which did produce as much ppGpp as the parented strain also formed $40-70 \mu \mathrm{g}$ formycin $\mathrm{ml}^{-1}$. Thus, the ability to accumulate ppGpp was correlated with the ability to produce formycin. The decreased ability of rel mutants to accumulate formycin could not be attributed to an increased ability to inactivate formycin; formycin added exogenously to cultures of the mutant strains did not decrease in concentration upon incubation. In addition, the final $\mathrm{pH}$ values of the culture media of the parental strain and mutants were similar, suggesting that rel mutants did not accumulate abnormal amounts of acidic or alkaline metabolites.

If the sporulation medium was supplemented with $0.05 \%$ tyrosine, the parental strain but not the rel mutants produced a black pigment (melanin). Although the rel mutants retained their ability to form aerial mycelium and spores when cultured on sporulation medium, the amounts of aerial mycelium were less and the onset of formation of aerial mycelium was delayed considerably (5-7 d) compared with that of the parental strain (1-2 d). Furthermore, addition of a small amount of polypeptone $(0.1-0.2 \%)$ to the medium suppressed completely the development of aerial mycelium in rel mutants but not in the parental strain. As in $E$. coli (Stephens et al., 1975), the rel mutation rendered growth more sensitive towards an amino acid analogue, DL-serine hydroxamate.

\section{Changes in nucleotide pool after nutritional shift-down}

In B. subtilis, Sterlini \& Mandelstam (1969) proposed a shift down for timely initiation of sporulation, where the cells were transferred from a glutamate $+1 \%$ Casamino acids medium to a replacement medium containing glutamate as the sole carbon source. Because the cells have to adapt to the absence of amino acids, the stringent response might be transiently effective; changes in nucleotide pools in $B$. subtilis cells after shift down suggested this was the case (Lopez et al., 1981). I used a similar approach to study whether or not Streptomyces sp. exerts the stringent response (i.e. accumulation of ppGpp or pppGpp) during amino acid starvation.

The parental and one of the rel mutants (32) were grown to mid-exponential phase in synthetic medium supplemented with $1 \%$ Casamino acids, harvested by filtration and immediately resuspended in fresh synthetic medium (without Casamino acids). Cells of the parental strain accumulated ppGpp immediately after shift down, while cells of the rel mutant accumulated ppGpp to only $15 \%$ of that amount (Fig. 4).

In contrast, when the parental strain and rel mutant 32 were grown to exponential growth phase in synthetic medium, filtered and transferred to glucose-deficient synthetic medium, both strains accumulated $125-130 \mathrm{pmol}$ ppGpp (mg dry wt) ${ }^{-1}$ after 10-20 min (data not shown). Thus, strain 32 still retained the ability to accumulate ppGpp during glucose starvation, as is the case for rel mutants of $E$. coli.

\section{Formycin production after shift down}

Since the rel mutation resulted in a sharp decrease in the ability to produce formycin, it was possible that conditions causing ppGpp to accumulate might also increase the ability of cells to produce formycin. This was examined after deprivation of Casamino acids, wherein cells accumulated large amounts of ppGpp (see Fig. 4). To test this idea, cells of both the parental strain $\left(\mathrm{rel}^{+}\right)$and $\mathrm{rel}$ mutant were grown in synthetic medium supplemented with Casamino acids 


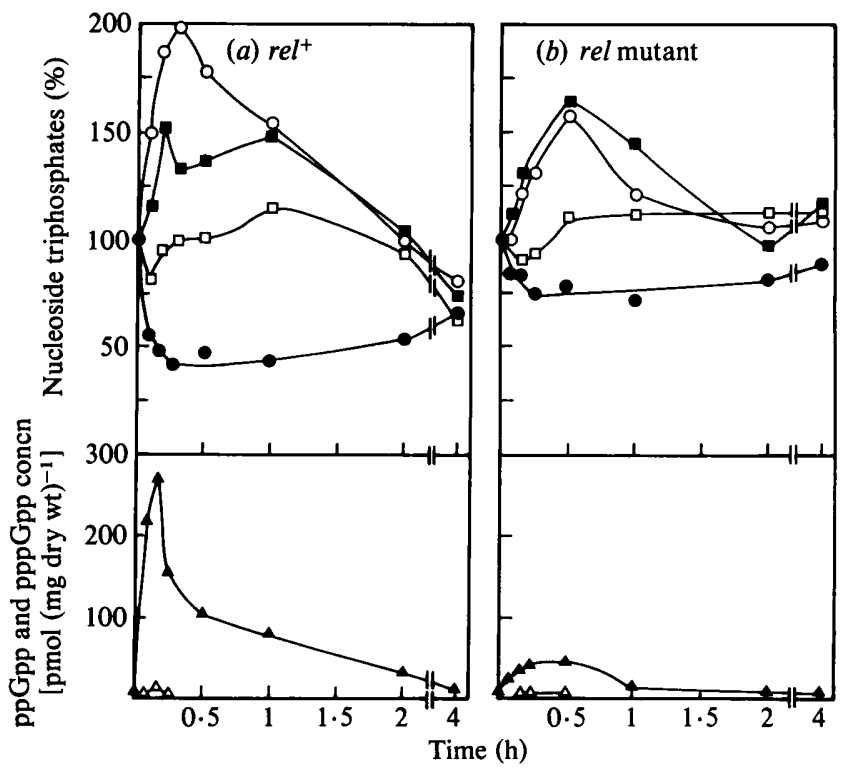

Fig. 4

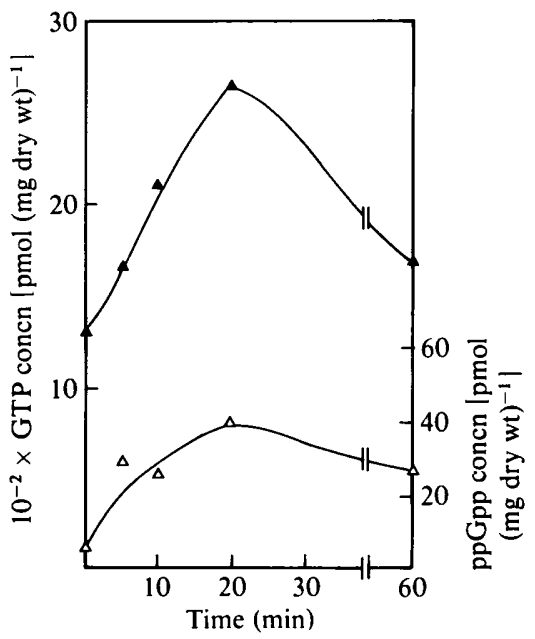

Fig. 5

Fig. 4. Changes in the intracellular concentrations of nucleoside triphosphates, ppGpp and pppGpp after shift down from synthetic medium containing $1 \%(\mathrm{w} / \mathrm{v})$ Casamino acids to synthetic medium lacking Casamino acids. Cells of $(a)$ parental strain or $(b)$ mutant 32, grown to mid-exponential phase in synthetic medium plus $1 \%(\mathrm{w} / \mathrm{v})$ Casamino acids as in Fig. 2, were harvested and transferred to fresh synthetic medium without Casamino acids, and then incubated at $30^{\circ} \mathrm{C}$ with shaking. At the indicated times, cells were filtered and extracted and the nucleotides were separated and quantified by HPLC (see Methods). Just before the transfer of cells to conditions without Casamino acids, the concentrations of nucleotides [pmol (mg dry wt) ${ }^{-1}$; designated as $100 \%$, measured in two separate experiments and averaged, were (parent) GTP, 1580; ATP, 2920; CTP, 722; UTP, 1040; (strain 32) GTP, 1680; ATP, 2790; CTP, 674; UTP, 1520. O, GTP; O, ATP; $\square$, CTP; $\square$, UTP; $\triangle$, ppGpp; $\triangle$, pppGpp.

Fig. 5. Changes in the intracellular concentrations of ppGpp and GTP during deprivation of Casamino acids in the presence of chloramphenicol. Cells of the parental strain were grown in synthetic medium plus $1 \%(w / v)$ Casamino acids and transferred to synthetic medium containing chloramphenicol $\left(2 \mu \mathrm{g} \mathrm{m}^{-1}\right)$ and growth was continued for $60 \mathrm{~min}$. Other procedures were the same as in Fig. 4. $\triangle$, GTP; $\triangle$, ppGpp.

(as described above) and shifted down nutritionally by harvesting and transferring the cells to one-half and one-third of the original volume of fresh synthetic medium (cell density $2 \cdot 2-2.5 \mathrm{mg}$ dry wt $\mathrm{ml}^{-1}$ ). Cells of both strains were also grown, in parallel, in synthetic media without Casamino acids supplement but transferred to fresh medium as described above. These transferred cultures were all incubated with shaking for $8 \mathrm{~h}$. Formycin production by $\mathrm{rel}^{+}$cells deprived of Casamino acids was drastically enhanced after a $2 \mathrm{~h} \mathrm{lag}$; increase in formycin titre was eightfold higher in cells shifted down than in those grown throughout in the synthetic medium. The rel cells did not produce any detectable amount of formycin under either of these experimental conditions.

Low levels of chloramphenicol inhibit the synthesis of both ppGpp and pppGpp without affecting cell growth of $B$. subtilis (Ochi \& Freese, 1983). With Streptomyces sp., low levels of chloramphenicol $\left(2 \mu \mathrm{g} \mathrm{ml}^{-1}\right)$ similarly blocked accumulation of ppGpp induced by deprivation of Casamino acids (compare Fig. 5 with Fig. $4 a$ ). Virtually no change in growth rate was observed upon the addition of $2 \mu \mathrm{g}$ chloramphenicol ml-1 as determined after deprivation of Casamino acids, but $8 \mu \mathrm{g}$ chloramphenicol $\mathrm{ml}^{-1}$ caused $50 \%$ inhibition of the growth rate.

When cells of the parental strain were shifted down from medium containing Casamino acids, their increased ability to produce formycin could be blocked by the immediate re-addition of $1 \%$ Casamino acids or of chloramphenicol $\left(2 \mu \mathrm{g} \mathrm{ml}^{-1}\right)$; however, after 2-3 h, addition of Casamino 


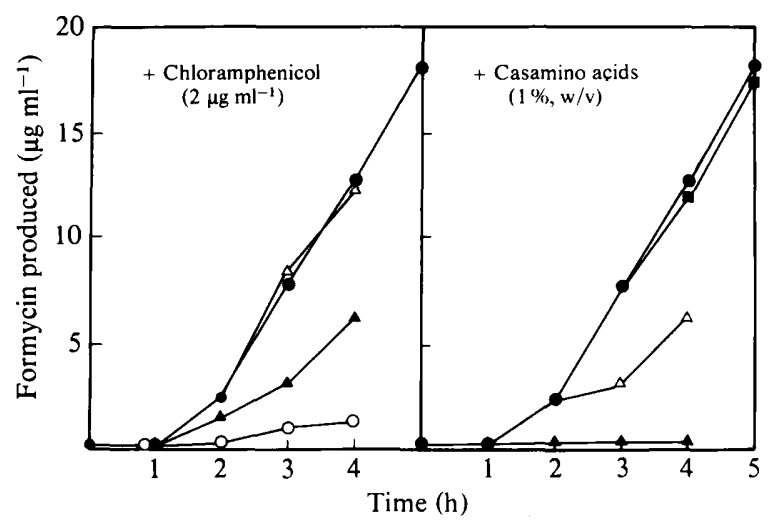

Fig. 6. Effect of chloramphenicol or Casamino acids on formycin production initiated by deprivation of Casamino acids. Cells of the parental strain were grown with $1 \%(w / v)$ Casamino acids as in Fig. 4 and then harvested and transferred to one-third of the original volume of fresh synthetic medium, giving $2.2 \mathrm{mg}$ dry wt cells $\mathrm{ml}^{-1}$. Cultures were divided into five samples which were incubated at $30^{\circ} \mathrm{C}$. At various times, chloramphenicol $\left(2 \mu \mathrm{g} \mathrm{ml}^{-1}\right)$ or Casamino acids $(1 \%, w / v)$ was added to one of the flasks and the formycin titre in the medium was measured at the times indicated. No addition and addition at: $O$, zero time; $\Delta, 1 \mathrm{~h} ; \Delta, 2 \mathrm{~h} ; \boldsymbol{\square}, 3 \mathrm{~h}$.

Table 1. Effect of glucose deprivation on formycin production in the presence or absence of chloramphenicol

The results are means of four separate experiments and varied by $\pm 20 \%$ for formycin produced per cell and by $\pm 15 \%$ for $p p G p p$.

\begin{tabular}{|c|c|c|c|c|}
\hline Strain & $\begin{array}{l}\text { Transferred from } \\
\text { synthetic medium } \\
\text { to }\end{array}$ & $\begin{array}{c}\text { Chloram- } \\
\text { phenicol } \\
\left(2 \mu \mathrm{g} \mathrm{ml}^{-1}\right)\end{array}$ & $\begin{array}{c}\text { Formycin } \\
\text { produced } \\
\text { per cell }{ }^{*} \\
{\left[\mu \mathrm{g}(\mathrm{mg} \text { dry } \mathrm{wt})^{-1}\right]}\end{array}$ & $\begin{array}{c}\text { ppGpp } \dagger \\
{[\text { [pmol (mg dry wt) }}\end{array}$ \\
\hline $\begin{array}{l}\text { Parent } \\
\left(\mathrm{rel}^{+}\right)\end{array}$ & $\begin{array}{l}\text { Glucose-deficient } \\
\text { synthetic medium } \\
\text { Synthetic medium }\end{array}$ & $\begin{array}{l}- \\
+ \\
\overline{+}\end{array}$ & $\begin{array}{l}4 \cdot 6 \\
4 \cdot 6 \\
1.5 \\
0.8\end{array}$ & $\begin{array}{r}136 \\
63 \\
22 \\
7\end{array}$ \\
\hline $\begin{array}{l}\text { Mutant } 32 \\
(\text { rel })\end{array}$ & $\begin{array}{l}\text { Glucose-deficient } \\
\text { synthetic medium } \\
\text { Synthetic medium }\end{array}$ & $\begin{array}{l}- \\
+ \\
+\end{array}$ & $\begin{array}{r}3.8 \\
1.3 \\
0.3 \\
<0.2\end{array}$ & $\begin{array}{r}122 \\
68 \\
14 \\
12\end{array}$ \\
\hline
\end{tabular}

* Determined $10 \mathrm{~h}$ after transfer.

$\dagger$ Determined 20 min after transfer.

acids or chloramphenicol had no effect on formycin synthesis (Fig. 6), indicating that the stringent response has to function for $2-3 \mathrm{~h}$ to complete the initiation of formycin production.

Because the rel mutant could accumulate ppGpp during glucose starvation, it was worthwhile to examine formycin-producing ability under such conditions. Glucose deprivation after transfer from synthetic medium arrested growth completely during $10 \mathrm{~h}$ incubation (but DNA synthesis continued at half rate for at least $4 \mathrm{~h}$ ), and during this period the rel mutant produced formycin to about the same extent as did the $\mathrm{rel}^{+}$parental strain (Table 1). Thus, the ability to produce formycin was tightly coupled with the accumulation of ppGpp.

\section{Curing of formycin production}

Culture of Streptomyces sp. MA406-A-1 with acridine dye resulted in a high frequency (about $50 \%$ ) of colonies that had lost the ability to produce formycin (S. Yashima, personal communication), which is a result similar to that seen for antibiotic production by numerous 
other Streptomyces species (Okanishi \& Umezawa, 1978). After deprivation of Casamino acids these cured strains accumulated as much ppGpp as did the parental strain.

\section{DISCUSSION}

In bacteria, differentiation and induction of secondary metabolism start concomitantly in response to nutrient limitation. How do bacteria sense such adverse environmental conditions? The results of this study indicate that in Streptomyces sp. MA406-A-1 ppGpp may be an early signal, produced in response to nutrient limitation, which may trigger events such as formycin production. This suggestion is supported by the response of the parental strain both to nutritional shift-down and to chloramphenicol and by the behaviour of the rel mutants.

This is the first report of the isolation of rel mutants (32 and 123) in streptomycetes; they might be tentatively classed as relC mutants, in analogy with mutants of $E$. coli and $B$. subtilis, which lack ribosomal protein L11 (Smith et al., 1978, 1980), but further work will be required to confirm this classification directly. Under glucose deprivation the cells of the rel mutants of Streptomyces sp. MA406-A-1 accumulated as much ppGpp as cells of the wild-type strain, a result consistent with what has been reported in E. coli (Lazzarini et al., 1971; Friesen et al., 1974).

The GTP pool size of $\mathrm{rel}^{+}$(but not rel) cells decreased extensively after deprivation of Casamino acids concomitant with the increased levels in ppGpp (Fig. 4). Since ppGpp (and pppGpp) inhibits IMP-dehydrogenase of E. coli and B. subtilis (Gallant et al., 1971; Wu \& Scrimgeour, 1973), which plays a role in GMP (and thus GTP) synthesis, the elevated levels of ppGpp may be responsible for the decline in the GTP of Streptomyces sp.

The ability to produce formycin was strongly correlated with the stringent response, suggesting that ppGpp may initiate (directly or indirectly) formycin production. In support of this suggestion is the fact that the rel mutation also abolished streptomycin production by Streptomyces griseus (unpublished observations). The only seeming disharmony was the lack of effect of chloramphenicol on formycin production by the $\mathrm{rel}^{+}$strain during glucose deprivation (see Table 1). Conceivably, $\mathrm{rel}^{+}$cells grown in synthetic medium had already been committed to produce formycin and this commitment was not abolished because of the absence of further growth, so that inhibition of ppGpp accumulation no longer affected formycin-producing ability. However, the results do not reveal anything about the molecular mechanism of ppGpp function, i.e. a role in transcription or translation. The decrease in GTP content per se, which presumably resulted from ppGpp accumulation, cannot be a signal for formycin production (Ochi, 1986). The sharp decrease in GTP pools associated with the observed stringent response may also play a role in the initiation of aerial mycelium formation. The delayed appearance of aerial mycelium in the rel mutants is consistent with this notion (Fig. 4; also Ochi, 1986). The relatively high ppGpp accumulation during growth in synthetic medium could be a reason for growth-associated formycin production. In fact, the addition of Casamino acids lowered the ppGpp pool size (Fig. 1), and suppressed formycin production throughout exponential growth. The occurrence of ppGpp in various Streptomyces species (Hamagishi et al., 1981; Nishino \& Murao, 1981) and its possible relationship to antibiotic production (An \& Vining, 1978; Simuth et al., 1979; Stastna \& Mikulik, 1981) have been reported.

Antibiotic production has been most frequently described from a viewpoint of 'negative' regulatory features (Martin \& Demain, 1980; Demain et al., 1983), and it is frequently suppressed by high levels of carbon, nitrogen and phosphate. In E. coli, cAMP is involved in carbon catabolite repression. Although cAMP occurs in Streptomyces species (Gersch, 1979; Colombo et al., 1982; Ensign, 1982; Surowitz \& Pfister, 1985), it is uncertain whether it has an essential role in catabolite repression. In contrast with such negative regulations, compounds which 'positively' function have been reported recently. Mutants of $S$. griseus or Streptomyces griseoflavus lacking A-factor or defective in arginine synthesis, respectively, were deficient both in aerial mycelium formation and antibiotic production, but both processes could be restored by adding A-factor or citrulline (Kleiner et al., 1976; Hara \& Beppu, 1982; Ochi, et al., 1984). At present, it is entirely unknown whether effects elicited by ppGpp could be superimposed on the positive and negative regulatory effects mentioned above. Such a possible interaction might be at least partially resolved by using the rel mutants described. 
This paper is dedicated to Ernst Freese for his sixtieth birthday. The author thanks S. Yashima and Y. Okami for supplying Streptomyces sp. MA406-A-1, and T. Shomura for kindly donating formycin. J. H. Hageman, Professor of New Mexico State University, is thanked for his valuable advice, and H. Aoki and M. Kohsaka for encouragement to proceed with this study.

\section{REFERENCES}

AN, G. \& VINING, L. C. (1978). Intracellular levels of guanosine 5'-diphosphate 3'-diphosphate (ppGpp) and guanosine 5 -triphosphate $3^{\prime}$-diphosphate (pppGpp) in cultures of Streptomyces griseus. Canadian Journal of Microbiology 24, 502-511.

BLOCK, R. \& Haseltine, W. A. (1973). Thermolability of the stringent factor in rel mutants of Escherichia coli. Journal of Molecular Biology 77, 625-629.

CASHEL, M. (1975). Regulation of bacterial ppGpp and pppGpp. Annual Review of Microbiology 29, 301-318.

ChATER, K. F. (1984). Morphological and physiological differentiation in Streptomyces. In Microbial Development, pp. 89-116. Edited by R. Losick \& L. Shapiro. Cold Spring Harbor, New York: Cold Spring Harbor Laboratory.

Chater, K. F. \& MerRick, M. J. (1979). Streptomyces. In Developmental Biology of Prokaryotes, pp. 93-114. Edited by J. H. Parish. Oxford: Blackwell.

Colombo, A. L., Crespi-Perellino, N. \& Micalizio, S. (1982). Relationships between growth, cyclic AMP and tylosin production in two mutants of Streptomyces fradiae. Biotechnology Letters 4, 747752.

Demain, A. L., Aharonowitz, Y. \& Martin, J.-F. (1983). Metabolic control of secondary biosynthetic pathways. In Biochemistry and Genetic Regulation of Commercially Important Antibiotics, pp. 49-72. Edited by L. C. Vining. Reading, Mass.: AddisonWesley.

ENSIGN, J. C. (1978). Formation, properties and germination of actinomycetes spores. Annual Review of Microbiology 32, 373-392.

ENSIGN, J. C. (1982). Developmental biology of actinomycetes. FEMS Symposium 13, 127-140.

FilL, N. \& FrIESEN, J. D. (1968). Isolation of relaxed mutants of Escherichia coli. Journal of Bacteriology 95, 729-731.

FREESE, E. (1981). Initiation of bacterial sporulation. In Sporulation and Germination - Proceedings of the VIII International Spores Conference, pp. 1-12. Edited by H. S. Levinson, A. L. Sonenshein \& D. J. Tipper. Washington, DC: American Society for Microbiology.

Freese, E. \& HeInze, J. (1984). Metabolic and genetic control of bacterial sporulation. In The Bacterial Spores, Volume 2, pp. 101-172. Edited by A. Hurst, G. W. Gould \& J. Dring. London: Academic Press.

Friesen, J. D., Fill, N. P., Parker, J. M. \& Haseltine, W. A. (1974). A new relaxed mutant of Escherichia coli with an altered $50 \mathrm{~S}$ ribosomal subunit. Proceedings of the National Academy of Sciences of the United States of America 71, 34653469.

Gallant, J. A. (1979). Stringent control in E. coli. Annual Review of Genetics 13, 393-415.

Gallant, J. A., IrR, J. \& Cashel, M. (1971). The mechanism of amino acid control of guanylate and adenylate biosynthesis. Journal of Biological Chemistry 246, 5812-5816.
GERSCH, D. (1979). Dependence of macromolecule synthesis on cyclic AMP in antibiotic producing strains of Streptomyces hygroscopicus. FEMS Microbiology Letters 6, 343-347.

Hamagishi, Y., Yoshimoto, A. \& OKI, T. (1981) Determination of guanosine tetraphosphate (ppGpp) and adenosine pentaphosphate (pppApp) in various microorganisms by radioimmunoassay. Archives of Microbiology 130, 134-137.

HARA, O. \& BEPPU, T. (1982). Mutants blocked in streptomycin production in Streptomyces griseus the role of A-factor. Journal of Antibiotics 35, 349 358.

Hensens, O. D. \& Albers-Schönberg, G. (1983a). Total structure of the highly modified peptide antibiotic components of thiopeptin. Journal of Antibiotics 36, 814-831.

HeNSENS, O. D. \& Albers-SCHÖNBERG, G. (1983b). ${ }^{13} \mathrm{C}$ NMR study of thiostrepton and thiopeptin components. Journal of Antibiotics 36, 832-845.

KAISER, D. (1984). Regulation of multicellular development in myxobacteria. In Microbial Development, pp. 197-218. Edited by R. Losick \& L. Shapiro. Cold Spring Harbor, New York: Cold Spring Harbor Laboratory.

Kalakoutski, L. V. \& Agre, N. S. (1976). Comparative aspects of development and differentiation in actinomycetes. Bacteriological Reviews 40, 469-524.

Kleiner, E. M., Pliner, S. A., Solfor, V. S., ONOPRIENKo, V. V., Balashova, T. A., Rozynov, B. V. \& KHOKHLOV, A. S. (1976). Structure of the Afactor, a bioregulator from Streptomyces griseus. Bioorganicheska khimiia 2, 1142-1147 (in Russian).

Lazzarini, R. A., Cashel, M. \& Gallant, J. (1971). Regulation of guanosine tetraphosphate levels in stringent and relaxed strains of Escherichia coli. Journal of Biological Chemistry 246, 4381-4385.

Lopez, J. M., Dromerick, A. \& Freese, E. (1981). Response of guanosine 5 -triphosphate concentration to nutritional changes and its significance for Bacillus subtilis sporulation. Journal of Bacterology 146, 605-613.

Martin, J. F. \& Demain, A. L. (1980). Control of antibiotic synthesis. Microbiological Reviews 44, 230 251.

Nishino, T. \& MURaO, S. (1981). Possible involvement of plasmid in nucleotide pyrophosphokinase production and the relationship between this productivity and cellular accumulation of guanosine tetraphosphate (ppGpp) in Streptomyces. Agricultural and Biological Chemistry 45, 199-208.

OCHI, K. (1985). Sporulation and antibiotic production by Bacillus subtilis mutants deficient in intracellular proteases. Agricultural and Biological Chemistry 49, 905-907.

OCHI, K. (1986). A decrease in GTP content is associated with aerial mycelium formation in Streptomyces MA406-A-1. Journal of General Microbiology 132, 299-305. 
OCHI, K. \& FREESE, E. (1983). Effect of antibiotics on sporulation caused by the stringent response in Bacillus subtilis. Journal of General Microbiology 129, 3709-3720.

OCHI, K. \& OHSAWA, S. (1984). Initiation of antibiotic production by the stringent response of Bacillus subtilis Marburg. Journal of General Microbiology 130, 2473-2482.

OCHI, K., Yashma, S., Eguchi, Y. \& Matsushita, K. (1979). Biosynthesis of formycin: incorporation and distribution of ${ }^{13} \mathrm{C}$-, ${ }^{14} \mathrm{C}$-, and ${ }^{15} \mathrm{~N}$-labeled compounds into formycin. Journal of Biological Chemistry 254, 8819-8824.

Ochi, K., Kandala, J. C. \& Freese, E. (1981). Initiation of Bacillus subtilis sporulation by the stringent response to partial amino acid deprivation. Journal of Biological Chemistry 256, 6866-6875.

OchI, K., Kandala, J. C. \& Freese, E. (1982). Evidence that Bacillus subtilis sporulation induced by the stringent response is caused by the decrease in GTP or GDP. Journal of Bacteriology 151, 10621065.

OCHI, K., SaIto, Y., Umehara, K., Ueda, I. \& KOHSAKA, M. (1984). Restoration of aerial mycelium and antibiotic production in a Streptomyces griseoflavus arginine auxotroph. Journal of General Microbiology 130, 2007-2013.

OKanishi, M. \& Umezawa, H. (1978). Plasmid involved in antibiotic production in streptomycetes. In Genetics of the Actinomycetes, pp. 19-38. Edited by E. Freerksen, I. Tarnok \& J. H. Thumim. Stuttgart: Gustav Fisher Verlag.

Parker, J., Watson, R. J. \& Friesen, J. D. (1976). A relaxed mutant with an altered ribosomal protein L11. Molecular and General Genetics 144, 111-114.

Riesenberg, D., Bergter, F. \& Kari, C. (1984). Effect of serine hydroxamate and methyl $\alpha$-Dglucopyranoside treatment on nucleoside polyphosphate pools, RNA and protein accumulation in Streptomyces hygroscopicus. Journal of General Microbiology 130, 2549-2558.
Simuth, J., Hudec, J., Chau, H. T., Danyi, O. \& ZeLINKA, J. (1979). The synthesis of highly phosphorylated nucleotides, RNA and protein by Streptomyces aureofaciens. Journal of Antibiotics 32, 53-58.

Smith, I., Paress, P. \& PestKa, S. (1978). Thiostrepton-resistant mutants exhibit relaxed synthesis of RNA. Proceedings of the National Academy of Sciences of the United States of America 75, 59935997.

Smith, I., Paress, P., Gabane, K. \& Dubnau, E. (1980). Genetics and physiology of the rel system of Bacillus subtilis. Molecular and General Genetics 178, 271-279.

Stastna, J. \& Mikulik, K. (1981). Role of highly phosphorylated nucleotides and antibiotics in the development of Streptomyces. In Actinomycetes, pp. 481-486. Edited by K. P. Schaal \& G. Pulverer. Stuttgart \& New York: Gustav Fisher Verlag.

Stephens, J. C., ARTS, S. W. \& AMES, B. N. (1975). Guanosine $5^{\prime}$-diphosphate $3^{\prime}$-diphosphate (ppGpp): positive effector for histidine operon transcription and general signal for amino acid deficiency. Proceedings of the National Academy of Sciences of the United States of America 72, 4389-4393.

Sterlini, J. \& MANDElstaM, J. (1969). Commitment to sporulation of Bacillus subtilis and its relationship to development of actinomycin resistance. Biochemical Journal 113, 29-37.

Surowitz, K. G. \& Pfister, R. M. (1985). Variations in levels of cAMP, DNA and RNA in Streptomyces alboniger under conditions of aerial mycelium formation and repression. FEMS Microbiology Letters 26, $1-4$.

Swanton, M. \& Edlin, G. (1972). Isolation and characterization of an RNA relaxed mutant of $B$. subtilis. Biochemical and Biophysical Research Communications 46, 583-588.

Wu, T.-W. \& SCRImgeour, K. G. (1973). Properties of inosinic acid dehydrogenase from Bacillus subtilis. II. Kinetic properties. Canadian Journal of Biochemistry 51, 1391-1398. 